\title{
The College English Writing Teaching Reform in the big Data Bases Era
}

\author{
Xia Wang ${ }^{1, a}$ \\ ${ }^{1}$ Foreign Language Teaching and Research Department, Jilin University of Finance and Economics, \\ China \\ aKennan2008@126.com
}

Keywords: Big data bases, College English, Writing teaching, Reform

\begin{abstract}
With the rapid development of science and technology in China, all kinds of mobile terminals and the fusion of computer technology are using. People exclaim "era of big data" brings. At this stage, no matter what kind of activities carried out is inseparable data, teaching college English writing is no exception either. Through the investigation we found that the characteristics of Big Data Era College English Writing provides great convenience to continuously promote the teaching model of development, but it also brings new challenges for the university teaching of English writing, so conduct in-depth is researched on this topic .
\end{abstract}

\section{Introduction}

With the wide application of Internet technology at present stage, we began to acute the big data age. The main characteristic of this era is the large amount of information, information transmission speed, this information will not be able to use database tools of the past were analyzed, and thus related technology as a cloud began to appear [1]. The emergence of cloud technology shows that we have started to use this feature, so as to better living and learning. Through research we found that the coming of the era of big data provides powerful conditions for college English writing teaching, promoting the innovation of college English writing teaching approaches and, therefore, we must attach importance to the research of this topic [1]. This paper on the era of big data the significance of the reform of college English writing teaching in-depth analysis, and then, combined with the data of the development of related technologies, analysis the main characteristics of the era of big data, and finally, then present the data in the present situation of the application in college English writing teaching, so as to put forward under the era of big data, the reform of college English writing teaching approaches.

\section{The significance of college English writing teaching reform in era of big data bases}

Innovation teaching mode, to improve students' interest in learning. Data can break the traditional English teaching mode, it will be the teaching content of organic fuses in together, in the exercise the students' English writing ability in the teaching process, and to some extent compensate for the traditional English teaching, the teaching content piece of separation [1]. At the same time, the reform of English teaching patterns are significantly improved the students' learning enthusiasm. In the era of big data under reform of college English writing teaching, the students can study in a more relaxed, more pleasant atmosphere for the related content, and study to further improve the students' interest in learning English.

Improve the efficiency of English writing teaching. In the process of traditional English writing teaching, the teacher often use cramming teaching model, students tend to "ear into the ear", English teaching efficiency is relatively low [2]. Through the reform of teaching mode, through to the teaching goal setting and the cooperation between students learning, can arouse the enthusiasm of students to learn actively, in order to complete the corresponding writing task, students tend to digest what they have learned content. 
Rich writing content and form. Computer writing teaching under the network environment is one of the advantages of students in writing can retrieve specific topic related content [2]. Internet search engine provides many specialized retrieval tools, easy to find. Digital library of online electronic resources, and also from the popular magazines, all kinds of resources to academic journals, academic monographs. Through this way, students can fully use of network resources, rich content and form of writing.

\section{The main characteristics of the era of big data in English teaching}

In the era of big data, people, according to the development of modern science and technology in the past to change the way of teaching, from the previous pursuit of high-speed into the pursuit of efficiency, this provides the daily life of people with great convenience (such as Fig.1 shown). At the same time, change the way of teaching to a certain extent, promote the teaching reform.

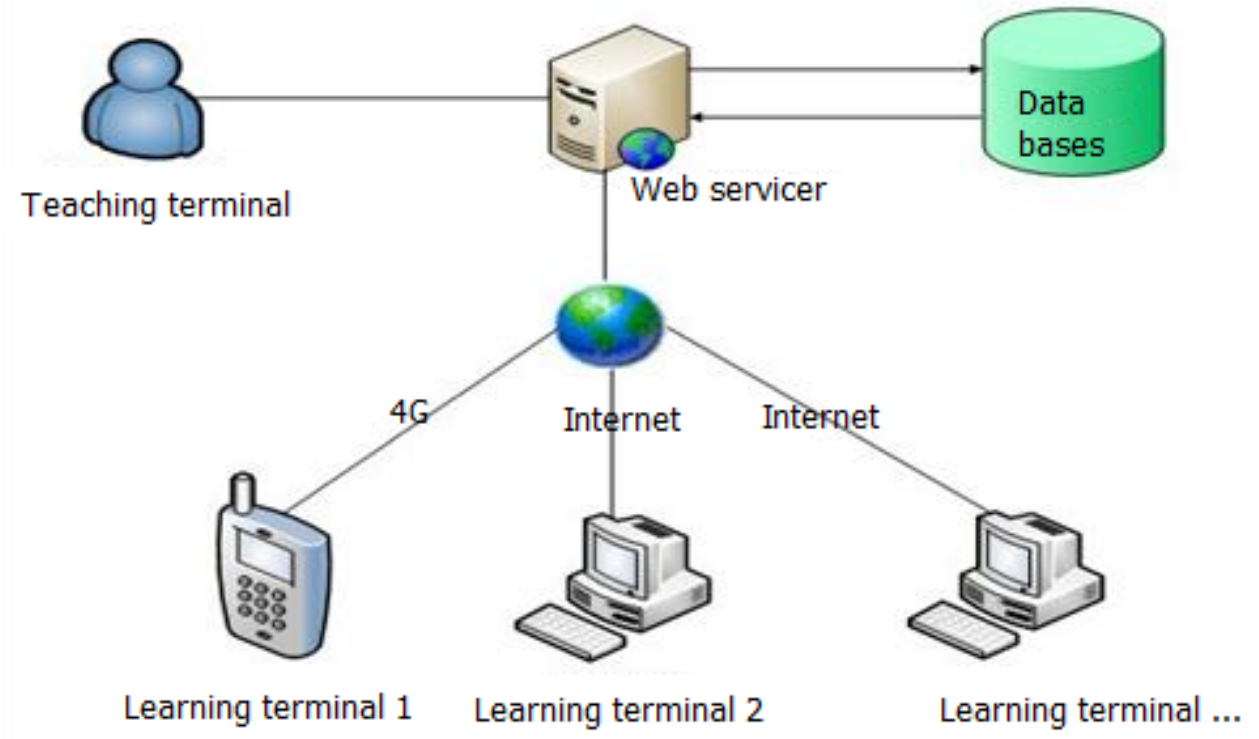

Fig.1 Big data teaching mode

The teacher's role change.Teachers are no longer the sole occupant of knowledge and provider, and become the organizers of the classroom and study guide. English description of the change is that the more interesting organizer and guide is not good when: the teacher wants to learning content is very familiar with, and know how online video can provide public class; At the same time, best can know learners' characteristics, personality, cognitive style, learning methods, learning purpose, special experience, etc.)[2]. In other words, the teacher prepares a lesson quantity will not reduce, only revealed a reduction in the class; And ready to must answer the question, will widen the range of thinking, content will be varied, differ in thousands ways. In addition, teachers grasp of the education technology would be taken for granted.

A few teachers will become public class video speaker or a director. Provide public class teachers, the teaching concept should be a complete transformation: he didn't know online courses class move; His face tens of thousands, tens of different levels, different interest from all over the world, different elective students learning method; Content of accurate, clear and simplified properly, expression, and attract students, such as the strong and persistent is a great challenge for him. For example, video to modular - accounts for only $3 \sim 5$ minutes, each theme convenient students use spare time to watch; Important knowledge must embed interactive problem, the convenient students timely check effect; Involves the background information to embed hyperlinks, convenient students links to online resources first, then immediately return to the same place [3]. In the future to courses as a carrier of video will be overtaken by production, accumulation and elimination, and precipitation.

The learner role transformation. Learners become real center: he decided to learn what where and when to learn, how to learn, to learn, learn much, much faster. The learner's initiative to give full play to out [3]: first of all, he is not computer blind, but to mastery network technology. Second, he 
should take the initiative to understand all the information about the course, including his own responsibility, the responsibility of the teacher, the responsibility of the administrator, etc., to determine their elective professional and curriculum. Third, he must inform within limits in the network, complete course assignments, enough credits, etc as required. Fourth, he have plenty of time and absolute initiative, individual determination and hard work determines his future. The students are required to have high self-consciousness, self-discipline, perseverance, self management ability, etc.; Drift, liberal, inability to discipline students encounter difficulties. There will be a weak-willed rare or spoiled students, attracted by the gossip on the network information, have a crush on no three no four games, movies, gambling, etc, become the victim of the era of large data.

Big data era is different: teachers from "father", "authority" to the mentor, helper, negotiators much more equal relationship between teachers and students. Students became the center, is the service object, infinite expanded self development space, can no longer be squeezed into a unified into the same mold in models of products.

\section{The reform of college English writing teaching in era of big data}

According to the present situation of the application in college English writing teaching, and puts forward the following the era of big data the reform of college English writing teaching approaches, the main contents are as follows.

Change teaching mode. The ultimate goal of college students to learn English is to be able to skillfully use English this language, so we in the teaching of college English writing language as a basis for a comprehensive understanding of writing content, then the characteristics of the era of big data fully applied to teaching of English writing teaching mode, guide the student to carry on the independent writing [4]. Under the background in the era of big data, college English teachers in the teaching of English writing teaching plans should be open-minded, to the needs of students as the main body, thereby multi-angle thinking, have the courage to discard the traditional teaching as the main form of teaching, actively introduce advanced and effective way to teach English writing. For example, we can use more information technology to college English writing teaching, teachers can make full use of network resources, education significance for finding the relevant students more familiar with and aspects of film and television works as writing material, rich content and form of writing. In addition, we also can adopt the group cooperative learning teaching mode, lets the student in the cooperative writing training, so as to improve the students' interest in learning, to promote all-round development of students.

In the era of big data under the background of writing the text mode innovation. Under the background of the era of big data, the creation of the English text can be a personal behavior, also can be the result of the collective cooperation; It can be done once, also can be modified to be repeated. At the same time, the meaning of a text will also be different, therefore, college English teachers in teaching design, should be thought from multiple perspectives. For example, we need to continue to twist a book report writing. The traditional teaching method is the teacher of the relevant structure of the book report and asking for language teaching, and then let the students to write, in the end, the teacher to evaluate the related works [4]. But, under the background of big data at present stage, the writing mode has been unable to meet the needs of students, therefore, we can make the text writing mode innovation. First of all, before the relevant book report writing, teachers should according to the students of the selected readings for the characteristics of the related book report, students should according to the characteristics of the book report to adjust the selected readings; Second, is the process of students' writing. In this process, students can use a variety of intelligent retrieval or correction tool to improve the quality of writing.

Good writing teaching evaluation system. Under the background in the era of big data, college English teaching process is dependent on the information [5]. We need network teaching platform for writing materials collected, the submission of student work, the teacher corrects the homework to the student and the teaching form of present teaching activities such as support, therefore, we will writing teaching evaluation system combined with the corresponding teaching activity fully, constantly updating the teaching material, changing the teaching way, simplify the teaching process, etc., thus 
promotes the improvement of college English writing teaching. Big data technology, for example, can according to analysis of students' online activities and the students in the aspects of vocabulary, syntax and discourse levels, comprehensive analysis of the students' ability and related faults, and then to improve.

English teacher fully cooperation with information technology personnel. In order to better to reform the teaching mode, we should also promote the English teachers of cooperation with relevant information technology staff, in this way, the English teacher can be in the technology on the basis of full understanding of the relevant information to the change of teaching mode, at the same time, relevant information technology staff can fully understand the laws of English writing teaching, to better developed suitable for college students' writing software in study and teaching system [5]. Through the cooperation of the two can constantly improve the level of college English writing teaching.

Improve teachers' information technology application ability. In the era of big data bring convenience to English teaching at the same time, we also want to notice the big data to the teachers' ability to use information technology put forward higher request, in the era of big data, the teacher is not only a imparter of knowledge, but also organizer and director of the teaching activities, therefore, the related English teachers should constantly update their knowledge of information technology, application of information technology fully, in order to improve the quality and application level, relevant professional improve the teaching efficiency of English writing.

\section{Summary}

Students through the above reform of college English writing teaching under the big data age approaches the subject of in-depth analysis we can find that in the era of big data under the necessity of the reform of college English writing teaching, therefore, we should attach great importance to the deep analysis of the subject. From the above we can see that at this stage in the process of the reform of college English writing more problems, resulting in college students' English writing ability can't get promoted, which affects the students' all-round development. Based on the current data in the present situation of the application in college English writing teaching, so as to put forward more than the era of big data the reform of college English writing teaching approaches, hoping to promote the improvement of college English writing teaching.

\section{References}

[1] Zh.L. Liu and J.L. Zhang, Based on the education of information resource integration framework research of cloud, Intelligence Journal, 2013, pp.10-16.

[2] H.B. Li and L.J. Mao, Build research based on data integration of university information standards, Education information in China, 2011, pp.10-15.

[3] N. Wang, Student teaching creative writing - experience digital writing, Chinese foreign language students, 2014, pp. 68-73.

[4] Y.L. Yang, Students facing the globalization, English teaching information technology, the digital age - based on the "Experience English Writing" Research and Training system construction, Foreign language teaching and foreign language students, 2012, vol.05, pp. 20-26.

[5] X.Y. Shan and W.L. Li, Research and Practice of English Writing Teaching social interactive mode, The Heilongjiang Higher Education Research. 2005, pp. 12-17. 